\title{
Innovation and adaptation in advocacy organizations throughout the Digital Eras
}

James Dennis ${ }^{1}$ and Nina Hall ${ }^{2}$

${ }^{1}$ School of Film, Media and Communication, University of Portsmouth

${ }^{2}$ Johns Hopkins School of Advanced International Studies, Bologna, Italy

\begin{abstract}
This special issue explores how digitally-native advocacy organizations evolve and whether they influence the organizational norms of other NGOs and advocacy groups. The volume offers three contributions to the literature on digital advocacy groups. Firstly, we argue that different periods of 'internet time' influence the tactics, strategies, and structural form of political organizations. Secondly, we examine different ways that organizations empower members and/or the broader public to make decisions using digital technology. Thirdly, we trace the diffusion of digital engagement practices, as well as how legacy advocacy groups have adapted these practices. Finally, we provide an agenda for future research. Specifically, research is needed on changes in digital organizing in Africa, Asia, and Latin Amerca, and centre-right and far-right advocacy organizations. Further work is also necessary to identify the conditions that lead to innovation in digital advocacy.
\end{abstract}

Keywords: activism; campaigning; political advocacy; temporailty; digital media

Forthcoming in Journal of Information Technology and Politics, 2020

"Author's Accepted Manuscript," January 10, 2020, for UK Research Excellence Framework eligibility. Please read and cite the final copyedited and typeset version of this article, which can be found here: https://www.tandfonline.com/loi/witp20 
In August 2016, Becky Bond and Zack Exley, two leading experts of digital campaigning, presented "Rules for Revolutionaries: A Guide to Big Organizing" to a crowded room of digital advocacy organizations in Berlin. Bond and Exley had just finished an intense few months working as senior advisors to the Bernie Sanders' campaign for the 2016 Democratic Party's nomination, and they wanted to share the lessons they had learned with other advocacy organizations. In the room were activists from Amandla.Mobi (South Africa), ActionStation (New Zealand), \#aufstehn (Austria), De.Clic (Romania), Uplift (Ireland), Skiftet (Sweden), Uplift (Ireland) and Zazim (Israel). All are part of the Online Progressive Engagement Network (OPEN) (see Dennis, 2018; Hall, 2019; Karpf, 2016). ${ }^{1}$ Bond and Exley emphasized the importance of handing over power to volunteers to lead actions. As they put it, "the revolution will not be staffed," and so most work needs to be done by volunteers. Advocacy organizations should aim to "distribute" their work, have a centralized plan, and combine digital campaigning with offline actions. Their presentation was an example of how new best practices in digital advocacy emerge and diffuse. ${ }^{2}$

Scholars of political communication have examined how the digital era is reshaping political organizations (Bennett and Segerberg, 2013; Bimber et al. 2012; Chadwick, 2007; Chadwick and Stromer-Galley 2017; Gerbaudo, 2018; Karpf, 2012). In particular, they have highlighted the emergence of digitally-native advocacy organizations. While authors in this special issue use slightly different terms to describe them, ${ }^{3}$ these organizations are characterized by the use of digital technologies to run member-driven campaigns across multiple issues. Many of these new 'hybrid' organizations (Vromen 2017), are part of the OPEN network. Although there has been significant research on individual digital advocacy organizations within their national context (Chadwick and Dennis, 2017; Dennis, 2018 on 38 Degrees; Karpf, 2012; 2016 on MoveOn; Vromen, 2017 on GetUp), there has been little comparative analysis of these organizations. Furthermore, there have been no systematic attempts to understand whether digitally-native advocacy organizartions have affected organizational practices and forms of traditional Non-Governmental Organizations (NGOs) and civic associations across the digital eras (Karpf, 2016).

In this special issue, we tackle these gaps in the literature. This special issue began with a workshop on "Understanding and Examining the Digital Pioneers" at the University of Portsmouth in September 2018, which occurred 20 years after MoveOn was formed. Our working hypothesis was that digitally-native organizations, such as those which are part of OPEN, are at the forefront of innovations in digital campaigning, whether that be the integration of analytics in decision-making (Karpf, 2016) or the strategic deployment of digital 
micro-targeting (Dennis, 2018). Beyond this, we wanted to know how digital advocacy organizations evolve and whether they influence the organizational norms of other NGOs and advocacy groups.

To answer these questions, we invited scholars to examine these organizational practices. The articles in this special issue offer in-depth case studies from a broad range of political organizations working across the globe, including digitally-native advocacy organizations (Karpf, 2020; Vaughan, 2020), political party factions in the UK (Dennis, 2020), legacy NGOs (Macintyre, 2020; Trevisan et al. 2020; Schmitz et al. 2020), and social movements in Zimbabwe (Chitanana, 2020). ${ }^{4}$ These case studies provide insider perspectives of the opportunities, challenges, and tensions that accompany the integration of digital tools. In doing so, this research goes beyond examining organizations' 'digital footprint' (i.e. the traces that organizations leave online). Instead, the articles here provide descriptive accounts of how advocacy groups use digital technologies and why.

Specifically, the findings presented in this special issue have three main implications for the study of digital advocacy groups (see Table 1). Firstly, we need to consider how different periods of 'internet time' influence the tactics, strategies, and structural form of political organizations (see Karpf, 2020). By observing the digital landscape when new organizations are formed, scholars can understand how time-sensitive technological affordances shape campaigning (Chitanana, 2020).

Secondly, we need to investigate the full spectrum of ways that organizations use digital technology to distribute power to members and/or the broader public to make decisions. None of the organizations studied within this special issue align with ideas of controlled interactivity entirely (Kreiss, 2012; Stromer-Galley, 2014), under which the leadership of an organization seeks to control and shape the digital participation of activists; neither do they resemble horizontal, leaderless movements (see crowd-enabled networks, Bennett and Segerberg, 2013). Instead, this special issue illustrates more fluid organizational structures, which provide enhanced levels of agency for supporters while retaining the strategic expertise of the leadership (Dennis, 2020; Macintyre, 2020; Schmitz et al. 2020).

Thirdly, this special issue traces the diffusion and adaptation of digital engagement practices by legacy advocacy groups (Macintyre, 2020; Trevisan et al. 2020; Schmitz et al. 2020). Furthermore, Vaughan (2020) provides a comparative case study to demonstrate the significant differences that exist amongst hybrid campaigning organizations, such as 38 Degrees and GetUp, despite the similarities in structural form. 
Table 1. Summary of articles in the special issue

\begin{tabular}{|c|c|c|c|}
\hline Authors & $\begin{array}{l}\text { Geographic } \\
\text { Focus }\end{array}$ & Method & Key Findings \\
\hline Karpf & Global & Theory-based & $\begin{array}{l}\text { Studies in digital politics that draw on the idea } \\
\text { of the "digital age" as a uniform phenomenon } \\
\text { overlook the significance of temporality. New } \\
\text { technologies bring new affordances that shape } \\
\text { organizational practices and participatory } \\
\text { norms. }\end{array}$ \\
\hline Dennis & UK & $\begin{array}{l}\text { Discourse } \\
\text { analysis of } \\
\text { posts from } \\
\text { Facebook and } \\
\text { Twitter and } \\
\text { interviews }\end{array}$ & $\begin{array}{l}\text { Momentum represents a movement faction, } \\
\text { drawing on the affordances of social media } \\
\text { platforms to provide flexible modes of } \\
\text { organizing at different spatial levels. }\end{array}$ \\
\hline Vaughan & $\begin{array}{l}\text { Australia } \\
\text { and UK }\end{array}$ & $\begin{array}{l}\text { Topic } \\
\text { modelling, } \\
\text { network } \\
\text { analysis and } \\
\text { interviews }\end{array}$ & $\begin{array}{l}\text { In contrast to their shared organizational } \\
\text { structures and repertoires of action, } 38 \\
\text { Degrees (UK) and GetUp (Australia) draw on } \\
\text { discourse within campaigns that is specific to } \\
\text { local national context. }\end{array}$ \\
\hline Chitanana & Zimbabwe & $\begin{array}{l}\text { Document } \\
\text { analysis and } \\
\text { interviews }\end{array}$ & $\begin{array}{l}\text { By tracing the formation and campaigning of } \\
\text { six advocacy groups (Kubatana, Sokwanele, } \\
\text { Magamba, Baba Jukwa, OAUS, and } \\
\text { \#ThisFlag), this article traces the evolution of } \\
\text { digital activism in Zimbabwe. The political } \\
\text { environment, alongside changes in } \\
\text { technological affordances, shaped the } \\
\text { structural transformation of activist groups. }\end{array}$ \\
\hline $\begin{array}{l}\text { Trevisan, } \\
\text { Vromen, } \\
\text { Bello \& } \\
\text { Vaughan }\end{array}$ & USA & $\begin{array}{l}\text { Network } \\
\text { mapping on } \\
\text { LinkedIn and } \\
\text { interviews }\end{array}$ & $\begin{array}{l}\text { Describes and documents the diffusion of a } \\
\text { new practice developed from the tradition of } \\
\text { storytelling, digital story banking; "the } \\
\text { systematic and on-going large-scale collection, } \\
\text { digital archiving, and cataloguing of personal } \\
\text { stories for future development and } \\
\text { incorporation in advocacy initiatives." }\end{array}$ \\
\hline Macintyre & $\begin{array}{l}\text { Global (UK- } \\
\text { based } \\
\text { observation) }\end{array}$ & $\begin{array}{l}\text { Ethnography } \\
\text { and } \\
\text { interviews }\end{array}$ & $\begin{array}{l}\text { Amnesty International uses data-driven } \\
\text { methods to educate and mobilise supporters } \\
\text { around leader-defined strategic goals, rather } \\
\text { than to provide substantive forms of influence } \\
\text { in the decision-making process. }\end{array}$ \\
\hline $\begin{array}{l}\text { Schmitz, } \\
\text { Dedmon, }\end{array}$ & $\begin{array}{l}\text { Europe, } \\
\text { Latin }\end{array}$ & Interviews & $\begin{array}{l}\text { Legacy NGOs with a history of professional } \\
\text { staff-led campaigning are less comfortable }\end{array}$ \\
\hline
\end{tabular}




\begin{tabular}{lll}
\hline Vijfeijken \& & America, & than digital advocacy groups to cede \\
Mahoney & North & substantial control over strategy to supporters. \\
& $\begin{array}{l}\text { America and } \\
\text { South Asia }\end{array}$ & \\
& South
\end{tabular}

\section{Political advocacy examined across the Digital Eras}

An important theme running throughout this special issue is that the 'digital era' is not a uniform period but one that spans multiple and distinct phases of technological development. In the 1980 s and $1990 \mathrm{~s}$, the internet was treated as a separate 'cyberspace,' but today it is extremely difficult to differentitate between the 'online' and 'offline' world, especially as most of us are permanently connected to the internet through a multitude of smart devices. In addition, the internet of 1998, when MoveOn was born, is vastly different from the internet of 2019 (Karpf, 2020). Whereas early examples of digital campaigning were dominated by blogging and email, social media and digital analytics represent standard practice for an increasing number of advocacy groups today (Chadwick and Stromer-Galley, 2017).

This point has been made previously by various political communications scholars (see Bode and Vraga, 2017: 2). For instance, $\operatorname{Karpf}(2016)$ stated that there exists a "strong tendency among scholars of Internet politics to treat all digital media as though they share the same affordances, which are then contrasted with the affordances of older communications technologies" (p. 62). In this special issue, several articles take this argument further and suggest that we should have a much more granular analysis of how advocacy organizations' practices relate to the distinct period of internet time in which they operate.

Karpf's article in this special issue-“"Two Provocations for the Study of Digital Politics in Time" - makes a strong case for abandoning the distinction between the 'digital era' and the 'analogue era' as if these were the most significant distinctions in time. He recommends that scholars of political communication historicize their literature reviews by relating theories and concepts to the moment in internet time they were written in (i.e., web 1.0, web 2.0, or platform society). As he notes, “The digital advocacy pioneers of 1998 and 2005 have had to learn and adapt to the social media landscape of 2018" (Karpf, 2020). Therefore, Karpf encourages scholars to use historical institutionalism and ethnography to understand how an advocacy organization's practices are shaped by the distinct era in which they operate. 
Many other articles in the special issue also illustrate the importance of timing (or 'internet time') for shaping organizational practices and norms. Chitanana's (2020) article illustrates how Zimbabwean advocacy organizations adopted different forms and tactics depending on when they were established. For instance, Kubatana, which was founded in 2001 was an early leader in blogging, e-newsletters and email. In contrast, the \#ThisFlag movement, which was founded in 2016, began as a viral video disseminated through social media. Similarly, Dennis (2020) examines how the leadership of the Momentum, the political activist group founded in 2015 in the wake of Jeremy Corbyn's rise to leader of the Labour Party, uses Facebook to share provocative memes and humorous viral videos. This communication would not have been possible without the norms of digital culture that exist today. Trevisan, Vromen, Bello, and Vaughan (2020) show how advocacy organizations have adopted new methods of 'story-banking' to collect and disseminate stories from supporters. They suggest advocacy organizations often share these stories through social media platforms, rather than their own websites, because of the widespread uptake of social media in recent years.

Still other articles examine how digital organizations have changed their tactics as the internet has matured over time. For example, Vaughan (2020) contends that social media has replaced email as the dominant channel of communication online. This justifies his methodological approach: a focus on 38 Degrees' and GetUp's Facebook posts to study tax discourses in the UK and Australia. Meanwhile, older traditional NGOs, created before the internet era, have sought to emulate the mobilising power of digitally-native advocacy organizations (e.g. Macintyre's analysis of Amnesty International). And as Schmitz, Dedmon, Vijfeijken, and Mahoney (2020) point out many NGOs are struggling to adapt to the multiple changes in technology (and regulation) throughout internet time. Collectively these articles suggest there is intrinsic value to academics and practitioners in descriptive, qualitative, and empirical work that observes and documents digital innovations throughout internet time.

\section{Distributing power within organizations}

This special issue also explores questions about whether and how digital media enable more democratic, supporter-led decision-making. Several organizations analyzed here draw on the narrative of "people power" and claim that members have an enhanced level of influence through the use of new technologies (see Dennis, 2020 on Momentum; Macintyre, 2020 on Amnesty; Vaughan, 2020 on 38 Degrees). In fact, many digital campaigners have lauded the 
rise of "networked power", which comes from distributing power to their members through digital technology (Chadwick and Stromer-Galley, 2017; Timms and Heimans, 2018). However, existing research illustrates the need for such claims to be interrogated, distinguishing groups that provide genuine agency from those that seek to benefit from this discourse without offering substantive forms of influence (Gerbaudo, 2018; Kavada, 2019: 202).

Some organizations, predominantly political parties (Kreiss, 2012; Stromer-Galley, 2014), promote interactivity through actions that serve the leadership's ambitions. Described as "controlled interactivity" (Stromer-Galley, 2014: 177), citizens are tasked with the mobilization of other supporters - by promoting key messages and sharing their personal endorsement of a campaign — around leader-defined objectives. These parasocial interactions provide activists with a sense of agency without devolving power away from the leadership. This is in stark contrast to accounts of horizontal leaderless movements (Castells, 2015; Shirky, 2008) and forms of connective action (Bennett and Segerberg, 2013), in which responsibility for decision making and the coordination of political action is shared amongst supporters.

For many organizations in the OPEN network power is neither centralized nor completely distributed across the membership. As Karpf (2016; 2018) observes, these organizations prioritize forms of digital listening, tracking the demands of supporters by collecting online behavioral data (e.g. likes, clicks, shares). These digitally-expressed preferences provide feedback loops whereby grassroots members can have a meaningful influence over the selection of campaign priorities and the tactics adopted. In contrast to accounts of slacktivism, though liking, commenting, and sharing on platforms such as Facebook, members can guide the strategic direction of the group (Dennis, 2018). The leaders of groups like 38 Degrees and MoveOn still retain significant control in this model, acting as gatekeepers that draw on member feedback when designing and selecting campaigns (Chadwick and Dennis, 2017; Hall, 2019).

Involving citizens in this way is not without limitations. As Gerbaudo (2018) notes, while online decision-making tools enable supporters to vote and comment on proposals, these consultations are designed by the leadership. The framing and timing of these calls for participation can have a significant impact on whether or not supporters have meaningful agency. The examples provided in this special issue illustrate that providing opportunities for feedback does not necessarily translate to supporters being treated as coequal actors. This tension between interactivity and control is a common theme, albeit one examined from different theoretical traditions. 
Macintyre (2020) explores how the NGO, Amnesty International, has responded to other advocacy groups use of data-driven tools to decentralize decision-making processes. By contrasting the delegate model of representation, in which power is distributed to members, to the trustee model (Wahlke et al. 1962), where staff have ultimate control over strategy, Macintyre examines whether Amnesty's governance model is truly people-powered. Although staff at Amnesty recognize the potential of the approach adopted by organizations in the OPEN network, involvement, digital tools are used to educate and mobilize members on decisions taken by the leadership. The delegate model is overlooked, in part, due to the risks that greater grassroots involvement entails. These risks are developed in the contribution from Schmitz et al. (2020), who explore different approaches to supporter involvement in decision making amongst legacy NGOs and digital natives. Although leaders of all organizations seek to use digital tools to broaden participation in campaigns, legacy NGOs rely predominantly on staffled models of campaigning, delegating tasks to members around predetermined campaign goals.

This theme of controlled interactivity is one that permeates across case studies of innovations in organizational structure and practice in this special issue. Dennis' (2020) study of the UK-based movement faction, Momentum, illustrates how influence over strategic decision-making varies within the organization. While leaders at the national level instruct supporters to complete specific tasks concerning electoral goals, at the local level, supporters engage in forms of semi-autonomous community activism.

Trevisan et al. (2020) analyze a new tactic called story banking, or "the systematic and on-going large-scale collection, digital archiving, and cataloguing of personal stories for future development and incorporation in advocacy initiatives." This crowd-sourced practice clearly empowers citizens by providing a means for individual-level experiences to be amplified at strategically significant moments. However, professionals determine when these stories are deployed. As advocacy groups archive and manage these contributions from supporters in a more systematic way, a question of control emerges.

This special issue provides a snapshot of the extent to which digital technologies are being used by advocacy groups to diffuse decision-making responsibility to members. The findings illustrate that, despite the evident impact of many OPEN organizations, these norms have not been adopted by legacy NGOs or new organizations. Instead, we observe processes of learning and adaptation that straddle the delicate line between professional expertise and grassroots empowerment. 


\section{Adaptation and learning between political advocacy organizations}

A third major contribution of this special issue is to explore how both digitally-native and legacy advocacy groups are adapting to internet time, and learning from each other. These articles trace the processes of diffusion of new campaign tactics and organizational forms. They provide answers in particular contexts to: Where do best practices in digital advocacy emerge from? Who leads? Who innovates and how do these practices diffuse?

Collectively, the articles in this volume examine the diffusion and learning between digitally-native advocacy organizations and legacy groups that were formed in a pre-internet era. Precisely because this special issue covers a range of different organizations - from social movements, to legacy NGOs, to organizations in the OPEN network-it implicitly examines how learning can occur between sectors, as well as across geographies. Therefore, we can also examine the diffusion of 'best practices' across different types of organizations. In doing so, it contributes to a literature that is often split between those who primarily study the 'new' 'digital advocacy organizations, and those that study older, conventional NGOs (an exception is Hall et al. 2019).

Amongst these articles, there are examples of active teaching and learning (e.g. when people meet face-to-face, or through digital platforms, such as the Exley and Bond example at the beginning of this introduction). Trevisan et al. (2020) illustrate how the Center for American Progress was a real champion of story-banking and enabled learning across the civil society sector by developing free software that other smaller organizations could use.

There are also examples of more passive diffusion, where organizations emulate each other, without direct contact. Macintyre (2020) highlights how the staff at Amnesty feel the need to learn from the likes of Avaaz and Change.org, emulating these organizations in the adoption of $\mathrm{a} / \mathrm{b}$ testing for email campaigns. Meanwhile, Trevisan et al. (2020) show that Families USA has a "considerable indirect influence" on the diffusion of storybanking in the US, as around a fifth of all professional storybankers in their study have worked for the organization.

There are three important caveats to recognize when observing the diffusion of digital tactics. Firstly, this special issue illustrates how strategies are rarely copied but undergo a process of adaptation to fit organizational context. Macintyre (2020) and Schmitz et al. (2020) show how legacy NGOs are acutely aware of the risks involved with the decentralization of decision-making, and instead, seek to tap into the successful narratives and technologies pioneered by digitally-native advocacy groups to bolster existing campaigning practices. 
Secondly, learning does not necessarily have to be unidirectional. Even Momentum, a group founded on the back of a grassroots movement to elect Jeremy Corbyn as leader of the Labour Party, now - at the national level — draws on tactics developed by heavily centralized political parties (Dennis, 2020). Thirdly, spatial dynamics can be critical in explaining the differences that exist. Vaughan (2020) illustrates how the discourse used within campaign communication by 38 Degrees and GetUp differs substantially due to the local, national context, despite the similarities in structural form.

\section{Limitations of the special issue and future research}

This special issue, like any, has its limitations. Firstly, there is a need for more scholarship on changes in digital organizing in Africa, Asia, and Latin America (see Nyabola 2018). As we finalized this special issue in late 2019, protests were active in Chile, Hong Kong, Iran, Iraq, and Lebanon. We need to include, and foster, more academic scholarship from non-Western countries to see if the theories and trends identified here hold elsewhere. Scholars need to also factor in the digital divide and consider who in society benefits most from digital advocacy (see Schradie, 2019).

Secondly, this special issue neither examines centre-right nor far-right advocacy organizations. Scholars have noted the internet plays a "crucial role" for the far right's "ability to reach a great mass of people in a short amount of time at minimal expense" (Caini and Kroell, 2015: 336). Others have found that right-wing organizations are more successful than left-wing organizations at digital engagement as they use digital media to broadcast messages, rather than to try and facilitate engagement (Schradie, 2019). Further scholarship should examine whether the right or the left lead digital innovation, and to what effect. Is there evidence of any diffusion, emulation, or active learning occurring between groups on different ends of the political spectrum?

Thirdly, scholars should examine what leads to innovation in digital advocacy, and why specific organizations become pioneers. Trevisan et al. (2020) suggest that innovation in storybanking practices occurred when Trump came to power and advocacy organizations operated in opposition to the Federal Government. What other factors drive innovation? And will the 'digital pioneers' of today be the digital pioneers in 10 years-time? It's quite possible they will not. Digitally native organizations may not always be the first mover (or early adapter) to all 
new digital technologies. Some older organizations may leap-frog certain stages, and newer organizations may emerge in future, born out of new technological affordances.

Fourthly, scholars need to consider how regulation of social media will influence political advocacy. Over the last two years, there have been growing calls to curb the power of big tech companies. Social media platforms have faced widespread criticism from political leaders such as US Senator Elizabeth Warren and EU Executive Vice-President Margrethe Vestager. Facebook has been mired in political scandals: from Cambridge Analytica, to the more recent attack in Christchruch New Zealand where a white nationalist killed 51 Muslim worshippers and livestreamed it on Facebook Live.

In response, some tech companies are starting to regulate political content more actively, if not ban it completely. In October 2019, Twitter announced it would ban all political advertising, including "Ads that advocate for or against legislative issues of national importance (such as: climate change, healthcare, immigration, national security, taxes)" (Gadde, 2019). In November, Google announced restrictions on political adverts worldwide, with organizations no longer able to target citizens based on their supposed political preferences (Spencer, 2019).

We are entering a new phase of regulation of political advertising on social medialikely a combination of government-imposed and industry-developed self-regulation — which will limit and shape what advocacy organizations can do online. The internet today is no longer "the free public space" Castells described in 2015 that would lead to autonomous social movements and organizing. Future research will need to examine changes in internet technologies and also internet regulation over time. 


\section{References}

Bennett, W. L., \& Segerberg, A. (2013). The Logic of Connective Action: Digital Media and the Personalization of Contentious Politics. Cambridge, UK: Cambridge University Press.

Bimber, B., Flanagin, A. J., \& Stohl, C. (2012). Collective Action in Organizations: Interaction and Engagement in an Era of Technological Change. Cambridge, UK: Cambridge University Press.

Bode, L., \& Vraga, E. K. (2017). Studying Politics Across Media. Political Communication. $35(1), 1-7$.

Bond, B., \& Exley, Z. (2016). Rules for Revolutionaries: How Big Organizing Can Change Everything. Chelsea Green Publishing.

Caiani, M., \& Kröll, P. (2015). The Transnationalization of the Extreme Right and the use of the Internet. International Journal of Comparative and Applied Criminal Justice. 39(4), 331-351.

Castells, M. (2015). Networks of Outrage and Hope: Social Movements in the Internet Age. Cambridge, UK: Polity.

Chadwick, A. (2007). Digital Network Repertoires and Organizational Hybridity. Political Communication, 24(3), 283-301.

Chadwick, A., \& Dennis, J. (2017). Social Media, Professional Media, and Mobilization in Contemporary Britain: Explaining the Strengths and Weaknesses of the Citizens' Movement, 38 Degrees, Political Studies. 65(1), 42-60.

Chadwick, A., \& Stromer-Galley, J. (2016). Digital Media, Power, and Democracy in Parties and Election Campaigns: Party Decline or Party Renewal? The International Journal of Press/Politics. 21(3), 283-293.

Chitanana, T. (2020). From Kubatana to \#ThisFlag: Trajectories of Digital Activism in Zimbabwe. Journal of Information Technology \& Politics.

Dennis, J. (2018). Beyond Slacktivism: Political Participation on Social Media. Basingstoke, UK: Palgrave Macmillan.

Dennis, J. (2020). A Party Within a Party Posing as a Movement? Momentum as a Movement Faction. Journal of Information Technology \& Politics.

Gadde, V. [vijaya]. (2019, October 30). Tweet. Retrieved from https://twitter.com/vijaya/status/1189664481263046656

Gerbaudo, P. (2018). The Digital Party: Political Organisation and Online Democracy. London, UK: Pluto Press.

Hall, N. (2019). When Do Refugees Matter? The Importance of Issue Salience for Digital Advocacy Organizations. Interest Groups \& Advocacy. 8(3), 333-355.

Hall, N., Schmitz, H. P., \& Dedmon, M. (2019). Transnational Advocacy and NGOs in the

Digital Era: What's Changing and Why? International Studies Quarterly. https://doi.org/10.1093/isq/sqz052

Karpf, D. (2012). The MoveOn Effect: The Unexpected Transformation of American Political Advocacy. Oxford, UK: Oxford University Press.

Karpf, D. (2016). Analytic Activism: Digital Listening and the New Political Strategy. Oxford, UK: Oxford University Press.

Karpf, D. (2020). Two Provocations for the Study of Digital Politics in Time. Journal of Information Technology \& Politics. 
Kavada, A. (2019). The Movement Party - Winning Elections and Transforming Democracy in a Digital Era: Reflections on Paolo Gerbaudo's Chapter. In Chandler, D. and Fuchs, C. (eds.), Digital Objects, Digital Subjects: Interdisciplinary Perspectives on Capitalism, Labour and Politics in the Age of Big Data (pp. 199-204). London, UK: University of Westminster Press.

Kreiss, D. (2012). Taking Our Country Back: The Crafting of Networked Politics from Howard Dean to Barack Obama. Oxford, UK: Oxford University Press.

Macintyre, A. (2020). Adaption to Data-Driven Practices in Civil Society Organisations: A Case Study of Amnesty International. Journal of Information Technology \& Politics.

Nyabola, N. (2018). Digital Democracy, Analogue Politics: How the Internet Era is Changing Kenya. London, UK: Zed Books.

Schmitz H. P., Dedmon, J. M., Vijfeijken, T. B., \& Mahoney, J. (2020). Democratizing Advocacy? How Digital Tools Shape International Non-Governmental Activism. Journal of Information Technology \& Politics.

Schradie, J. (2019). The Revolution That Wasn't: How Digital Activism Favors Conservatives. Cambridge, MA: Harvard University Press.

Shirky, C. (2008). Here Comes Everybody: The Power of Organizing Without Organizations. London, UK: Allen Lane.

Spencer, S. (2019, November 20). An update on our political ads policy. Google. Retrieved from https://blog.google/technology/ads/update-our-political-ads-policy/

Stromer-Galley, J. (2014). Presidential Campaigning in the Internet Age. Oxford, UK: Oxford University Press.

Timms, H., \& Heimans, J. (2018). New Power: How it's changing the 21st Century - and why you need to know. London, UK: Macmillan.

Trevisan F., Vromen, A., Bello, B., \& Vaughan, M. (2020). Mobilizing Personal Narratives: The Rise of Digital "Story Banking" in U.S. Grassroots Advocacy. Journal of Information Technology \& Politics.

Vaughan, M. (2020). Talking about Tax: The Discursive Distance Between 38 Degrees and GetUp. Journal of Information Technology \& Politics.

Vromen, A. (2017). Digital Citizenship and Political Engagement: The Challenge from Online Campaigning and Advocacy Organisations. Basingstoke, UK: Palgrave Macmillan.

Wahlke, J. C., Eulau, H., Buchanan, W., \& Ferguson, L. C. (1962). The Legislative System: Explorations in Legislative Behavior. New York, USA: John Wiley. 
${ }^{1}$ The OPEN network consists of 19 organizations in 19 different countries worldwide. Full members are: MoveOn, (United States), GetUp, (Australia), Campact (Germany), 38 Degrees (UK), Leadnow (Canada), Skiftet (Sweden), ActionStation (New Zealand), Uplift (Ireland), \#aufstehn (Austria), Zazim (Israel), Akcja Demokracja (Poland). For a list of all the start-up organizations see https://the-open.net/network (last accessed 9 Dec 2019).

${ }^{2}$ One question that often came up: was whether other political advocacy organizations could apply Bond and Exley's lessons from the US Presidential primaries to other political contexts where there was not such a clear goal or deadline (i.e .getting your candidate elected President).

${ }^{3}$ Schmitz et al. (2020) use this term to describe groups within the OPEN network, such as Avaaz, but also include organizations that are not membership-based within this definition (e.g. Kiva). Macintyre (2020) refers to 'digital membership organizations', and Dennis (2020) uses 'hybrid campaigning organizations' when referring to organizations that are part of the OPEN network.

${ }^{4}$ Although we have tried to include organizations from a diverse range of countries, we should note that this special issue, like many others in political communication, is skewed in its analysis towards organizations in the global north. 